\title{
MEDIA DAN PENCIPTAAN KEPANIKAN MORAL: ANALISIS WACANA KRITIS TERHADAP PEMBERITAAN PANDEMI COVID-19 DI TIRTO.ID
}

\author{
Thomas Benmetan $^{1 *}$, Bhekti Setyowibowo ${ }^{2}$ \\ ${ }_{1,2)}$ Communication Science Department, Faculty of Economics and Communication, Bina Nusantara University, \\ Jakarta, Indonesia 11480 \\ Email: ${ }^{1}$ thomas.niko@binus.ac.id; ${ }^{2}$ bhekti.setyowibowo@binus.ac.id \\ *Penulis korespondensi
}

\begin{abstract}
ABSTRAK
Penelitian ini dilakukan untuk melihat bagaimana pandemi coronavirus dikomunikasikan kepada publik melalui pemberitaan media serta kaitannya dengan konstruksi narasi kepanikan moral. Data yang digunakan dalam penelitian ini dikumpulkan dari pemberitaan media online tirto.id tentang pandemi coronavirus sepanjang Maret hingga Agustus 2020. Dengan menggunakan Analisis Wacana Kritis sebagai metode penelitian, terdapat beberapa temuan menarik dalam studi ini. Pertama, penciptaan narasi kepanikan moral terhadap pandemi coronavirus di Indonesia dilakukan tirto.id dengan cara membingkai berita secara sensasional dan menekankan pada aspek-aspek tertentu dari pandemi sebagai magnifikasi isu. Kedua, ditemukan juga bahwa kepanikan moral adalah sebuah fenomena akar rumput yang dieskalasi melalui masifnya pemberitaan media. Selain itu, studi ini menunjukkan bahwa pembentukan wacana yang ada merupakan manifestasi dari kuasa media untuk membentuk penerimaan publik terhadap pandemi coronavirus di Indonesia. Kesimpulan dari penelitian ini memberikan gambaran bahwa publikasi tirto.id tentang pandemi coronavirus di Indonesia adalah manifestasi dari kekuatan media dalam membangun narasi, memengaruhi pandangan publik dan mendikte informasi.
\end{abstract}

Kata kunci: Kepanikan Moral, Analisis Wacana Kritis, Covid-19, Liputan Pandemi, Sensasionalisme.

\begin{abstract}
This study was conducted to see how the coronavirus pandemic is communicated to the public through media coverage, and its relation to the construction of the narrative of moral panic. The data used in this study were collected from tirto.id's coverage of the coronavirus pandemic in Indonesia from March to August 2020. Using Critical Discourse Analysis as a method, there are several interesting findings in this study. Firstly, the construction of moral panic narrative about the coronavirus pandemic in Indonesia was carried out by tirto.id in the ways they frame the news sensationally, and emphasize certain aspects of the pandemic as a magnification of the issue. Secondly, it was also found that moral panic is a grassroot phenomenon that was escalated through massive media coverage. In addition to that, this study showed that the construction of the existing discourse is a manifestation of the power of the media to shape public acceptance of the coronavirus pandemic in Indonesia. This study concludes that the publication of tirto.id about the coronavirus pandemic in Indonesia is a manifestation of the power of the media in constructing narratives, influencing public views and dictating information.
\end{abstract}

Keywords: Moral Panic, Critical Discourse Analysis, Covid-19, Pandemic Coverage, Sensationalism.

\section{PENDAHULUAN}

Sejak pertama kali diumumkan kasus pertama di Indonesia pada 2 Maret 2020, coronavirus menjadi topik utama yang mendominasi laman utama media di Indonesia. Salah satu portal berita terkemuka dengan jumlah publikasi yang cukup tinggi tentang peristiwa ini adalah tirto.id. Sepanjang Maret hingga Agustus 2020, terdapat 79 artikel terkait pandemi coronavirus yang diterbitkan tirto.id dalam rubrik Mild Report. Rubrik ini umumnya berisi berisi laporan semi analisis sebagai upaya untuk meliput peristiwa dari perspektif lain yang didukung oleh data dan analisis mendalam berdasarkan data primer (Remotivi, 2017).

Di Indonesia, tirto.id melabeli dirinya sebagai platform media online yang berfokus pada jurnalisme presisi, yakni penerapan analisis mendalam serta laporan investigatif dalam setiap artikel yang dimuat. Dengan demikian, artikel di tirto.id cenderung lebih panjang serta terdiri dari tinjauan analitis, statistik, dan data. Tentu saja, ketika suatu peristiwa diberitakan secara komprehensif dan mendalam, meresap dan menonjol dari sisi agenda berita, maka akan dianggap lebih penting bagi publik (Wanta, Golan \& Lee, 2004). Demikian pula penyebaran berita tentang pandemi coronavirus ini akan mampu memengaruhi perhatian publik dan menyebarkan ketakutan di tengah-tengah masyarakat.

Menurut Gilman (2010), kata pandemi memiliki penggunaan metafora yang kuat, serta memiliki konsekuensi sosial dan emosional, karena istilah itu sendiri dikhawatirkan memicu kepanikan (global). Hal ini berarti bahwa ketika suatu penyakit dicap 
sebagai pandemi, kemungkinan besar yang akan dirasakan oleh masyarakat adalah ketakutan, kecemasan dan paranoia. Karena itu, pemberian label pandemi memberikan karakteristik yang kuat sebagai sesuatu yang tidak biasa, berbahaya, menakutkan, dan perlu ditanggapi dengan serius untuk mencegah dampak buruk yang akan ditimbulkan.

Berkaitan dengan itu, tentu saja peran media dalam peliputan pandemi tidak hanya sekadar menghasilkan karya jurnalistik, tetapi juga sebagai upaya untuk berperan sebagai sistem darurat yang penting selama masa kritis (Reynolds et al., 2014) dengan memberikan informasi aktual dan terkini kepada publik mengenai situasi genting tentang pandemi. Dengan demikian, dapat dikatakan bahwa liputan media tentang peristiwa pandemi sangat diperlukan. Sebab, liputan serupa tidak hanya berguna untuk menginformasikan publik, tetapi juga mendidik masyarakat dengan memberikan informasi yang akurat dan aktual mengenai peristiwa yang terjadi.

Walau demikian, media pun memiliki agenda sendiri yang tersirat melalui liputan beritanya, karena media tidak hanya memberi tahu kita apa yang harus dipikirkan, tetapi juga memberi tahu kita cara untuk berpikir (Ghanem, McCombs, \& Chernov 2009). Lebih lanjut lagi, Fairclough (1995) juga menyatakan bahwa berita membawa kekuatan penanda yang unik, yakni kekuatan untuk mewakili peristiwa dengan cara tertentu. Hal ini berarti bahwa ketika peristiwa digambarkan dengan cara tertentu, ada semacam kecenderungan untuk memengaruhi persepsi publik terhadap peristiwa itu sendiri, sebab laporan jurnalistik yang terdistorsi dapat menimbulkan harapan palsu dan ketakutan yang tidak beralasan (PLoS Medicine, 2008).

Sebab itu, cara media merepresentasikan isu-isu seperti pandemi adalah sesuatu yang menarik untuk ditelaah agar kita bisa memahami bagaimana wacana tersebut dibawa ke publik; baik itu untuk menginformasikan, memperingatkan, atau pun mengedukasi publik mengenai pandemi. Hal inilah yang menjadi landasan utama dari peneliti untuk mengkaji bagaimana tirto.id memberitakan isu pandemi coronavirus di Indonesia. Hal ini penting untuk dilakukan, mengingat bahwa media berperan sebagai salah satu platform komunikasi utama ketika terjadi krisis kesehatan di masyarakat. Peran tersebut bisa berjalan dengan baik bergantung pada reputasi media itu sendiri sebagai sumber informasi terpercaya seperti halnya informasi aktual yang disiarkan (Klemm, Das \& Hartmann, 2014).
Berdasarkan penjelasan di atas, maka penelitian ini berangkat dengan rumusan masalah sebagai berikut: Bagaimana wacana pandemi coronavirus di Indonesia dikonstruksi oleh tirto.id dalam pemberitaan yang dilakukan lewat rubrik Mild Report? Peneliti melihat bahwa media memengaruhi cara suatu isu digambarkan dan disampaikan kepada publik, karena metode pelaporan berita mengubah perilaku orang dan sikap mereka terhadap isu yang dimuat (Anwar et al., 2020).

Beberapa penelitian terkait isu kepanikan moral terhadap pandemi covid-19 pernah dilakukan sebelumnya. Ririn Purba (2020) dalam penelitiannya tentang kepanikan sosial akibat munculnya Covid-19 menemukan bahwa penggunaan media komunikasi baik itu media digital maupun media konvensional menjadi salah satu sumber terjadinya kepanikan masyarakat. Sementara itu, Satawedin (2020) yang meneliti tentang kepanikan moral terkait Covid-19 di Thailand menemukan bahwa awak media adalah penyebab terjadinya kepanikan moral di masyarakat. Penelitiannya menunjukkan bahwa sebanyak lebih dari $67 \%$ headline surat kabar yang ada di Thailand memiliki tendensi untuk menciptakan kepanikan moral dari pemilihan bahasa dan framing yang dilakukan oleh pihak media.

Penelitian - penelitian tersebut memberikan landasan yang kuat bagi peneliti untuk memelajari bagaimana konstruksi narasi kepanikan moral dari dalam tubuh media itu sendiri. Peneliti menekankan fokus pada pembentukan wacana kepanikan moral lewat kontruksi berita dan seleksi isu dalam pemberitaan pandemi. Dengan demikian, penelitian ini menyelidiki bagaimana peran media dalam mengatur dan membingkai suatu isu seperti pandemi coronavirus pada tataran wacana. Hal ini dilandasi pemahaman bahwa media, sebagai sumber utama pengetahuan, sikap dan ideologi masyarakat, baik elit maupun warga biasa (van Dijk, 1993), berfungsi sebagai instrumen sosialisasi dan memiliki dampak penting pada pementasan dan komunikasi emosi.

\section{TINJAUAN PUSTAKA}

\subsection{Kepanikan Moral dan Sensasionalisme Media}

Kepanikan moral adalah sebuah konsep yang pertama kali dikemukakan oleh Mcluhan untuk menjelaskan sesuatu yang berkaitan dengan pengaruh media terhadap kehidupan kita sehari-hari dan pola budaya kita yang berfokus pada kecemasan publik yang 
berulang terhadap teknologi baru (Ingraham \& Reeves, 2016). Konsep tersebut dibakukan sosiolog Stanley Cohen (2011) dengan menyatakan bahwa kepanikan moral adalah suatu keadaan dimana seseorang atau sekelompok orang muncul sebagai ancaman terhadap nilai-nilai dan kepentingan masyarakat. Menurut Cohen, ketika terjadi kekacauan dalam masyarakat, mereka (dalam hal ini polisi dan masyarakat umum) yang merasa terancam akan menghasilkan reaksi balik. Reaksi tersebut kemudian diperparah oleh jurnalis atau pun tokoh media massa yang "menerjemahkan" ancaman tersebut lewat pemberitaan yang dilakukan.

Cohen melihat bahwa kepanikan moral dihasilkan oleh media yang masyarakat adalah subjek utamanya. Ia juga membingkai istilah tersebut sebagai fenomena yang didorong oleh media, dengan mempertimbangkan bagaimana "media"-yaitu, media massa seperti televisi, surat kabar, dan radio - sangat penting dalam membangkitkan dan memicu kepanikan moral tentang perilaku folk devil atau setan rakyat serta subkultur terpinggirkan lainnya (Ingraham \& Reeves, 2016). Folk Devil sendiri adalah orang yang, mungkin terlibat dalam praktik jahat dan disalahkan karena mengancam budaya masyarakat, cara hidup, dan nilai-nilai sentral dalam masyarakat (Goode \& BenYehuda, 2009).

Senada dengan itu Monod (2017) dalam penelitiannya menyatakan bahwa peran media dalam konstruksi kepanikan moral dilakukan melalui tiga cara yakni: penguatan isu; penciptaan sosok folk devil; dan pengaturan agenda. Dalam upaya penguatan isu, media menggunakan tiga cara agar persoalan yang diangkat menjadi lebih besar dari kenyataan yang ada. Pertama, media menggunakan fitur-fitur prediktif terhadap peristiwa tersebut. Kedua, media menggunakan pilihan kata dan kalimat tertentu dalam menyusun berita dengan intensi untuk mengkomunikasikan makna dan simbol-simbol tertentu kepada audiens. Terakhir, media melakukan konvergen atau menghubungkan isu yang ada dengan isu yang lain.

Selanjutnya, penciptaan folk devil adalah dengan menampilkan satu figur yang digambarkan media sedemikian rupa agar menjadi sosok yang membawa ancaman terhadap situasi yang ada. Folk Devil sendiri umumnya adalah sosok ataupun figur nyata yang dianggap memiliki dampak buruk dari keadaan yang ada. Mengutip Goede dan Ben-Yehuda (2009), situasi seperti bencana nuklir, flu babi, flu burung, E. Coli, pemanasan global, ancaman penyakit, kecelakaan, masalah militer bisa memicu ancaman namun tidak memiliki sosok folk devil dalam wujud nyata. Dengan kata lain, peliputan media terhadap isu-isu tertentu bisa saja memiliki ataupun tidak memiliki figur folk devil yang menyebabkan kepanikan moral.

Tahapan yang ketiga adalah pengaturan agenda media. Pada tahap ini, media mendefinisikan natur dari ancaman yang ada serta melakukan pengambilan sikap terhadap situasi tersebut (Monod, 2017). Dalam penelitian ini, bisa didefinisikan bahwa tahapan ini berkaitan dengan bagaimana media mendefinisikan pandemi covid-19 sebagai suatu keadaan yang mengancam, kemudian menampilkan situasi tersebut dalam peliputan dan publikasi yang ada untuk membentuk pandangan publik terhadap keadaan yang ada.

Tiga elemen ini: penguatan isu, penciptaan folk devil, dan pengaturan agenda media dimanufaktur sedemikian rupa oleh media untuk memicu terjadinya kepanikan moral melalui pemberitaan yang dilakukan. Dengan cara tersebut, media menyoroti suatu peristiwa dengan cara tertentu yang menarik perhatian publik, membumbui isu yang ada agar memiliki kesan sensasional. Dalam kaitannya dengan kepanikan moral, Gabrial (2013) menyatakan bahwa sensasionalisme merupakan kontributor kunci dalam membesar-besarkan atau mengabaikan ancaman dari suatu isu. Hal ini berarti bahwa dalam sebuah berita sensasionalisme digunakan untuk 'bermain' dengan emosi pembaca. Dengan demikian, dapat dikatakan bahwa sebagai salah satu portal berita daring di Indonesia, tirto.id memiliki tanggung jawab moral yang cukup besar untuk membentuk pemahaman masyarakat tentang pandemi coronavirus di Indonesia, terlepas dari sensasionalisme yang tersirat dalam pemberitaan yang dilakukan.

\subsection{Framing dan Agenda-Setting dalam Pem- beritaan Media}

Sensasionalisme dalam pemberitaan media berkaitan dengan teknik framing, dalam artian bahwa ketika sebuah cerita dilebih-lebihkan atau diberi nada tertentu oleh penulis, maka penulis telah membingkai cerita itu dengan menggunakan elemen-elemen sensasional (Frye, 2005). Dalam kaitannya dengan penelitian ini, dapat dikatakan bahwa tirto.id sebagai media memiliki kewenangan untuk mengkonstruksi narasi pandemi coronavirus melalui framing dalam pemberitaan, yang mana tirto.id memiliki kendali penuh untuk menarik perhatian publik terhadap isu yang penting untuk disampaikan. 
Framing mengacu pada cara suatu peristiwa atau isu diorganisasikan, dipahami serta diinterpetasi. Contohnya pada isu-isu yang menjadi perhatian publik seperti pandemi, bencana alam, peristiwa politik dan sebagainya. Oleh sebab framing berkaitan dengan bagaimana wartawan mengkonstruksi peristiwa dan menyajikannya kepada masyarakat (Eriyanto, 2009), terdapat elemen-elemen tertentu di dalam berita yang menjadi penanda bagaimana framing diidentifikasi. Secara umum, adanya framing memungkinkan individu untuk dapat melokalisasi, merasakan, mengidentifikasi dan memberi label terhadap peristiwa peristiwa serta informasi (Sobur, 2009).

Sebagai proses yang memiliki landasan kognitif, efek framing bisa dilihat dari bagaimana suatu informasi diproses dan dipahami. Hal ini tentu saja menunjukkan bahwa dalam tahapan tertentu, framing beririsan ketat dengan agenda-setting. McCombs dan Ghanem (2001) menyatakan bahwa agenda-setting adalah sebuah teori tentang bagaimana bagian yang paling menonjol dari gambaran media tentang dunia ditransferkan ke kepala kita. Dengan kata lain, agenda media menentukan agenda publik

Dalam hubungannya dengan kepanikan moral, agenda-setting media berkontribusi terhadap bagaimana kepanikan itu tercipta. Ketika melihat agendasetting dalam pemberitaan tentang pandemi coronavirus di Indonesia, tirto.id sebagai media memanfaatkan kewenangannya untuk membuat agenda dalam peliputan dengan bertumpu pada pengambilan sikap seperti apa ketika isu-isu itu disajikan dalam bentuk berita. Artinya bahwa fokus utama dalam pemberitaan bertujuan untuk mengartikulasikan pemahaman tentang bagaimana media memproduksi agenda tertentu yang nantinya akan membangun narasi kepanikan moral. Hal ini merujuk pada apa yang Monod (2017) utarakan bahwa amplifikasi masalah dan pembentukan folk devil diperluas dan dipertajam melalui berbagai potongan opini baik dari media atau di media.

\section{METODE PENELITIAN}

Penelitian ini menggunakan pendekatan kualitatif dengan rumusan masalah terkait konstruksi wacana pandemi coronavirus di Indonesia dalam pemberitaan tirto.id. Pemberitaan media memengaruhi cara pandang publik terhadap suatu isu, dan dalam hal ini, ketergantungan publik terhadap liputan media tentang pandemi coronavirus di Indonesia dapat memberikan efek psikologis yang intens serta kemungkinan perubahan dalam perilaku seseorang.
Tirto.id dipilih sebagai subjek dalam penelitian ini dikarenakan konsistensinya dalam mempublikasikan liputan yang luas dan mendalam tentang pandemi coronavirus, lebih khusus lagi pada bulan - bulan awal pandemi ini masuk ke Indonesia. Tirto.id adalah perusahaan media milik swasta di Indonesia yang diluncurkan pada tahun 2016 dengan tujuan untuk memberikan liputan yang "jelas, mencerahkan, berwawasan, kontekstual, mendalam, investigasi, faktual, didukung oleh data (baik kuantitatif maupun kualitatif), dan dapat dipertanggungjawabkan" (tirto.id, 2016).

Sejak awal berdiri, tirto.id mengambil jalur berbeda dari mayoritas media online di Indonesia dengan berfokus pada publikasi reportase di bawah rel jurnalisme presisi, bahwa mereka percaya bahwa orang Indonesia, terutama para pembuat keputusan dan pengendali perubahan layak mendapatkan produk jurnalistik yang didasarkan pada data dan disampaikan dengan baik tanpa batasan waktu. Sampai saat ini, tidak ada kecenderungan politik dan ideologi tertentu yang dapat dikaitkan dengan Tirto, karena mereka juga merupakan independensi mereka sebagai platform media online yang berdiri di atas dan untuk semua kelompok, serta non-partisan dan tidak bekerja untuk kepentingan politik apapun (tirto.id, 2016).

Sepanjang periode Maret hingga Agustus 2020, tirto.id menerbitkan 79 artikel tentang pandemi coronavirus di Indonesia di bawah kanal khusus yang bernama Mild Report. Kanal ini merupakan rubrik khusus yang berisi laporan singkat mengenai isu - isu sosial signifikan yang dipublikasikan dua kali dalam seminggu. Artikel-artikel inilah yang dianalisis oleh peneliti untuk mengeksplorasi bagaimana tirto.id sebagai media mewacanakan pandemi coronavirus lewat pemberitaan yang dilakukan. Selain itu, jumlah publikasi yang besar ini disinyalir merupakan praktik kepenulisan jurnalistik yang memikat, menarik, merangsang, menggugah, membesar-besarkan, dan umumnya memancing respons emosional pembaca sehubungan dengan manifestasi sensasionalisme dalam liputan media.

Adapun metode yang dipakai dalam penelitian ini adalah Analisis Wacana Kritis. Norman Fairclough (1995) menggambarkan bahwa Analisis Wacana Kritis bertujuan "untuk secara sistematis mengeksplorasi hubungan kausalitas dan penentuan yang sering kabur antara (a) praktik diskursif, peristiwa dan teks, dan (b) sosial dan struktur budaya, hubungan dan proses; untuk menyelidiki bagaimana praktik, peristiwa, dan teks semacam itu muncul dari dan secara ideologis dibentuk oleh hubungan kekuasaan dan perebutan kekuasaan." 
Berdasarkan definisi tersebut, peneliti melihat bahwa Analisis Wacana Kritis menekankan pada struktur dalam wacana dapat memengaruhi model mental tertentu dan representasi generik dari penerima, terutama tentang bagaimana sebuah perspektif bisa dimanipulasi. Hal inilah yang menyebabkan peneliti memutuskan untuk menggunakan Analisis Wacana Kritis dalam studi ini, sebab metode ini mencakup berbagai area diskursus dengan bahasa sebagai elemen yang penting untuk dikaji. Bahasa, menurut Fairclough (2001) telah menjadi media utama dalam kontrol sosial mengenai kekuasaan, yang berarti bahwa dalam Analisis Wacana Kritis, fokus penelitian ini tidak hanya untuk mengetahui penerapan tata bahasa dalam diskursus, tapi juga tentang makna sosial politik dan fungsi didalamnya.

Karena itu, penelitian ini menggunakan kerangka Analisis Wacana Kritis milik Norman Fairclough yang berfokus pada bahasa media, mengingat bahwa struktur teks dalam wacana media memainkan peran penting pada interpretasi secara kontekstual. Selain itu, pola penggunaan bahasa di media pada dasarnya bisa digunakan untuk menganalisis struktur dominasi, diskriminasi, kekuasaan, dan kontrol yang tersembunyi, buram, dan terlihat seperti yang dimanifestasikan dalam bahasa (Wodak \& Meyer, 2016).

Dalam melihat bahasa sebagai sebuah wacana, proses analisis mencakup beberapa unsur seperti: teks, proses produksi dan interpretasi, hubungan antar teks, proses dan kondisi sosialnya, konteks situasional dan kelembagaan, serta struktur sosial di dalamnya (Fairclough, 2001). Peneliti mengambil sampel yang terdiri dari 79 artikel dalam rubrik Mild Report yang diterbitkan tirto.id sepanjang Maret - Agustus 2020. Pemilihan artikel yang diterbitkan pada rentang waktu tersebut dikarenakan bahwa pandemi coronavirus pertama di Indonesia terjadi pada Maret 2020, dan pada Agustus 2020 negara ini telah sepenuhnya beralih ke adaptasi pasca-pandemi (The Jakarta Post, 2020). Karena itu, dengan memilih berita tertentu yang terkait dengan pandemi coronavirus pada periode waktu tertentu ini, peneliti menekankan fokus pada bagaimana wacana Coronavirus di Indonesia dibangun oleh media sejak awal masuk ke Indonesia. Dalam melakukan hal ini, peneliti mengaplikasikan tiga tahapan dalam Analisis Wacana Kritis yang dikemukakan oleh Norman Fairclough. Ketiga tahapan tersebut dijelaskan oleh Fairclough (2001) sebagai berikut:

1. Deskripsi, tahap yang berkaitan dengan sifat formal teks;

2. Interpretasi, berkaitan dengan hubungan antara teks dan interaksi di dalam teks; dan
3. Eksplanasi, adalah tahapan yang menitikberatkan pada hubungan antara interaksi teks dan konteks sosial tempat teks diproduksi.

Masing-masing dari ketiga proses tersebut membutuhkan analisis yang berbeda seperti Analisis Teks untuk deskripsi, Analisis Pengolahan untuk interpretasi, dan Analisis Sosial untuk penjelasan. Analisis teks mencakup elemen-elemen tekstual yang membentuk struktur berita tersebut seperti kosakata, tata bahasa, dan struktur teks.

Sementara itu, analisis pengolahan dalam tahap interpretasi melihat bagaimana pemberitaan yang dilakukan tirto.id dikonsumsi dan diinterpretasikan oleh khalayak, dengan mempertimbangkan ideologi institusi dan sasaran pembaca di mana teks itu diproduksi. Pada tahapan ini, peneliti menganalisis bagaimana "teks" dan "konteks" sebagai interpretasi yang dihasilkan melalui kombinasi antara apa yang ada di dalam teks dan apa yang ada di dalam penafsir. Artikelartikel dikelompokkan sesuai dengan topik yang ada di liputan seperti sosial, ekonomi, kesehatan, kemanusiaan, dan politik terkait dengan pandemi coronavirus di Indonesia. Setelah mengelompokkan artikel, peneliti menafsirkan pola bahasa tekstual dan situasi kontekstual dalam artikel dalam skema interpretasi yang lebih luas. Dengan demikian, dipastikan tidak ada pengulangan dalam proses pengkodean dan penentuan sampel.

Tahapan yang ketiga adalah analisis sosial yang fokus pada unsur-unsur intertekstual yang melingkupi produksi teks, dalam hal ini pandemi coronavirus di Indonesia. Sebagai tahap akhir dari Analisis Wacana Kritis, langkah ini difokuskan pada hubungan wacana, proses perjuangan dan hubungan kekuasaan. Karena itu, peneliti mengkaji bagaimana situasi sosial, kelembagaan, dan politik menyusun wacana tentang pandemi coronavirus di Indonesia serta bagaimana situasi tersebut mempengaruhi cara tirto.id mengkonstruksi isu ini dalam pemberitaannya. Ada tiga aspek penting yang menjadi pedoman dalam melakukan analisis ini, yakni determinan sosial, ideologi, dan efek. Peneliti menggunakan ketiga aspek tersebut sebagai landasan analisis empiris terkait wacana pandemi coronavirus di Indonesia dan kaitannya dengan kepanikan moral.

Selain mengkaji bagaimana konstruksi pandemi coronavirus sebagai wacana dalam dalam pemberitaan tirto.id, penelitian ini juga melihat manifestasi sensasionalisme melalui penggunaan bahasa tekstual dalam liputan media. Hal ini berarti bahwa dalam 
liputan media tentang situasi kritis seperti pandemi, konstruksi bahasa tekstual dan tipifikasi semacam itu dapat merangsang emosi melalui penggunaan pilihan kata dan pengemasan linguistik yang intens atau ekstrem. Karena itu, penelitian ini juga bertujuan untuk mengetahui apakah pemberitaan yang dilakukan tirto.id memicu narasi kepanikan moral dengan penggunaan bentuk bahasa sensasionalisme.

\section{HASIL DAN PEMBAHASAN}

Setelah melakukan analisis mendalam terhadap 79 artikel tentang pandemi coronavirus di Indonesia yang dipublikasikan tirto.id sepanjang Maret hingga Agustus 2020, terdapat tiga hasil utama yang menjadi temuan dan pembahasan. Penjabaran masing-masing temuan dan analisis data adalah sebagai berikut.

\subsection{Sensasionalisme: Senjata Media dalam Penciptaan Folk Devil}

Temuan pertama dari penelitian adalah tirto.id menggunakan sensasionalisme sebagai cara untuk memproyeksikan folk devil terkait kepanikan moral terhadap pandemi coronavirus di Indonesia. Seperti dijelaskan sebelumnya bahwa dalam mengkonstruksi kepanikan moral, sensasionalisme berperan untuk menggemakan gaung suatu peristiwa sementara folk devil adalah sosok ancaman dan musuh yang merusak (Goode \& Ben-Yehuda, 2009).

Dalam situasi kepanikan moral akibat pandemi coronavirus, sosok Folk Devil tidak serta merta bisa ditentukan, karena penyebabnya adalah penyakit (Goode \& Ben Yehuda, 2009). Meski demikian, pembentukan sosok Folk Devil bisa dikonstruksikan dengan melihat pada karakteristik kasus dan sifat dari peristiwa tersebut, misalnya kepentingan moral dan apakah sosok yang dituduhkan sebagai folk devil memiliki akses terhadap kepentingan ekonomi serta sosial (Monod, 2017). Karena itu, tirto.id dalam pemberitaannya memproyeksikan sosok Folk Devil pada sosok yang dianggap bisa menjadi representasi dari pihak yang disalahkan dan memicu ancaman. Temuan penelitian ini menunjukkan bahwa tirto.id cenderung menggambarkan pemerintah Indonesia sebagai pihak yang harus disalahkan dalam kekacauan pandemi coronavirus ini. Dengan demikian, dapat dikatakan bahwa tirto.id membentuk pemerintah Indonesia sebagai Folk Devil dalam kepanikan moral terhadap pandemi coronavirus.

Dalam 79 artikel yang dipublikasikannya, proporsi liputan disampaikan dengan pola konstruksi yang spesifik: cenderung mengulang kata-kata emotif, memiliki bentuk kalimat deklaratif, serta membingkai isu dengan nada-nada persuasif tertentu. Beberapa artikel dipublikasikan pada awal pandemi menunjukkan bahwa pemerintah tidak mampu menangani wabah ini ketika pertama kali tiba di Indonesia, serta mengkritik keras pernyataan menteri kesehatan yang mengatakan tidak perlu memakai masker. Liputan yang lain juga mengikuti pola yang sama dalam menyikapi pemerintah, khususnya atas kelalaian mereka dalam menetapkan tindakan pencegahan terhadap pandemi. Pembingkaian seperti ini juga sejalan dengan apa yang dikatakan Cohen sebagai rujukan negatif secara terus-menerus terhadap Folk Devil yang kemudian mengakibatkan penghapusan konotasi positif atau netral sebelumnya yang mungkin mereka miliki (Cohen, 1972; Monod, 2017). Beberapa contoh lain adalah ketika tirto.id memproyeksikan pemerintah gagal mengendalikan panic buying, kekacauan di masyarakat, dan ketidaksiapan dalam menangani peningkatan kasus Covid-19 di Indonesia.

Sorotan negatif terhadap pemerintah dalam penanganan pandemi coronavirus di Indonesia juga diwarnai dengan penggambaran situasi ekonomi, sosial, kemanusiaan, kesehatan, dan politik secara emosional sebagai korban kesalahan pemerintah. Dalam sikap ini, Tirto dengan tegas melucuti semua karakteristik yang menguntungkan pemerintah dan menanamkan unsur-unsur negatif, apa pun kedoknya dengan cara yang eksplisit, stereotipikal, dan lebih tajam dari kenyataan (Goode \& Ben-Yehuda, 2009; Monod, 2017). Hal ini menunjukkan bahwa dalam liputan media tentang risiko kesehatan, nada emosional dan bahasa yang sarat emosi memengaruhi persepsi pesan yang secara berurutan meningkatkan persepsi risiko dan dalam skenario terburuk dapat didefinisikan sebagai sensasional atau dramatis (Klemm, Das \& Hartmann, 2016). Misalnya, pada artikel yang berjudul "Benarkah Flu Musiman Lebih Mematikan daripada Covid-19?" terdapat beberapa pengulangan kata yang berhubungan dengan kematian seperti kematian, mematikan, dan fatal.

Selain pengulangan kata, tirto.id juga cenderung menggunakan frasa seruan di sebagian besar artikel yang ada. Jenis frasa ini berkorelasi dengan kalimat yang mengungkapkan perasaan dan emosi yang kuat. Penggunaan ini bertujuan untuk memperkuat fakta dan informasi yang mendukung gagasan bahwa pandemi coronavirus bukan hanya masalah kesehatan, tetapi juga masalah serius yang mempengaruhi beberapa aspek kehidupan kita seperti sosial, ekonomi, politik, dan kemanusiaan. Dalam artikel 
berjudul "Salah Paham Pemerintah Berujung Kepanikan Massal Covid-19", kata-kata yang digunakan adalah klaim mentah, sesumbar, glorifikasi, jemawa, menggelikan, mendewakan, membuai masyarakat. Kata-kata ini digunakan untuk meningkatkan keterlibatan emosional seperti ketakutan dan kekhawatiran. Pada bagian ini, tirto.id menggunakan bahasa emotif dalam peliputannya untuk menunjukkan rasa simpatinya kepada publik dan menimbulkan anggapan bahwa mereka berpihak pada publik yang dalam situasi ini menjadi korban dari ketidakmampuan pemerintah dalam menangani pandemi.

Tirto.id juga mengungkapkan kekecewaannya terhadap pemerintah dengan menggunakan metafora gigit jari dan adu domba pada artikel berjudul "Tingkat Kepercayaan Pada Negara: Modal Penting Penanganan Covid-19". Kedua metafora ini merupakan kritik terhadap tindakan pemerintah yang tidak terarah dalam menangani pandemi. Dari penggambaran ini, bisa dilihat bahwa tirto.id menggunakan sensasionalisme sebagai kontributor kunci dalam magnifikasi ancaman (Gabrial, 2013) dari sosok Folk Devil dalam pandemi ini, yakni pemerintah Indonesia. Dengan kata lain, posisi pemerintah sebagai Folk Devil secara tidak langsung menempatkan masyarakat sebagai pihak yang dikorbankan dalam kepanikan moral terhadap pandemi coronavirus di Indonesia.

\subsection{Kepanikan Moral sebagai Erupsi Akar Rumput}

Temuan kedua dalam penelitian ini berkaitan dengan konstruksi kepanikan moral terhadap pandemi coronavirus di Indonesia yang melibatkan tiga aktor sentral yakni media, pemerintah dan publik. Bila dikaitkan kembali dengan definisi kepanikan moral oleh Cohen, maka dapat dikatakan bahwa asal mula kepanikan moral adalah dari situasi publik. Dalam hal ini, kepanikan moral bermula dari health-scares yang dialami oleh publik ketika pertama kali wabah coronavirus terjadi di Cina, yaitu keadaan ketika orang-orang secara kolektif mengalami rasa kekhawatiran yang akut terhadap masalah kesehatan yang muncul tiba-tiba, dalam durasi yang terbatas, dan hilang dengan cepat (Béland, 2013).

Dilihat dari perspektif erupsi akar rumput, dapat dikatakan bahwa erupsi kepanikan yang kurang lebih spontan ini merupakan hasil dari ketakutan dan kekhawatiran sebagian besar orang tentang suatu ancaman atau ancaman yang diduga (Goode \& BenYehuda, 2009) akan mengarah pada ketakutan yang lebih besar jika terus berlanjut. Akibatnya, ketika orang merasa takut akan sesuatu, terjadi kultur ketakutan yang kemudian menjadi kepanikan moral apabila ditumbuhkan dengan isu-isu dan ketertarikan tertentu (Monod, 2017). Karena itu, eskalasi ketakutan publik terhadap pandemi ini sendirilah yang menjadi salah satu faktor terbesar dalam penciptaan kepanikan moral.

Dengan demikian, dapat dikatakan bahwa publik adalah pusat dari kepanikan moral terhadap pandemi coronavirus di Indonesia. Dengan kata lain, kepanikan moral berasal dari masyarakat, diserap dan ditanggapi oleh pemerintah, kemudian diaksentuasi oleh media. Karena itu, dapat dikatakan bahwa liputan tirto.id tentang pandemi coronavirus di Indonesia berkontribusi dalam memperbesar ketakutan menjadi kepanikan, meskipun liputan sebelumnya diterbitkan untuk menginformasikan kepada masyarakat agar tenang dan tidak takut dengan pandemi, sebab kepanikan moral dalam liputan media dibuat dengan tujuan untuk membuat masyarakat tidak panik (Monod, 2017).

Pemerintah merespon kepanikan masyarakat ketika wabah pertama terjadi dengan menerbitkan regulasi, mekanisme pencegahan, dan kebijakan mengenai pengendalian kekacauan dan beberapa isu terkait. Tirto.id sebagai media kemudian terlibat dalam hal ini dengan mempublikasikan artikel tentang pandemi ini dalam berbagai topik yakni Sosial, Ekonomi, Kesehatan, Humaniora, dan Politik. Pada artikel tentang sosial, ekonomi dan politik, tirto.id cenderung menggunakan pola bahasa deklaratif. Artikel-artikel dalam kategori sosial menceritakan tentang perubahan sosial yang terjadi selama pandemi coronavirus, misalnya hobi baru untuk mengatasi kelangkaan makanan dan risiko pelanggaran privasi dalam skema pelacakan coronavirus oleh Apple dan Google. Dalam artikel-artikel tersebut, tirto.id memiliki kecenderungan untuk menggunakan pola bahasa deklaratif dalam konstruksi bahasa, yang berarti mereka ingin menyampaikan atau menyatakan informasi untuk mendahului pernyataan terhadap masalah terkait (Fairclough, 2003).

Sementara pada artikel kategori ekonomi dan politik, tirto.id lebih menekankan pada bencana ekonomi dan seberapa buruk tindakan pemerintah Indonesia dalam menangani pandemi. Misalnya, pada artikel berjudul "Indonesia Rawan Krisis Jika Lockdown Diberlakukan", pola bahasanya lebih banyak memuat pernyataan, penjelasan, dan bentuk kalimat langsung guna memperkuat pandangan mereka terhadap konteks situasional terkait krisis lockdown dan ketidak- 
percayaan publik terhadap pemerintah. Menghubungkan pola tekstual dan konteks situasional yang diangkat dalam artikel, dapat dikatakan bahwa tirto.id cenderung melegitimasi gagasan yang lebih luas bahwa situasi seperti masalah sosial dan kelemahan ekonomi tidak hanya dipengaruhi oleh pandemi coronavirus, tetapi juga oleh respon pemerintah yang kurang memuaskan.

Pada artikel-artikel yang berkaitan dengan kesehatan, tirto.id cenderung lebih pragmatis terhadap ketidakpastian konteks situasional selama pandemi. Artikel dalam kategori ini berisi isu-isu seperti pengecekan fakta atas klaim fenomenal terkait pandemi, teori konspirasi, hoax, vaksin, kesehatan mental, dan sebagainya. Pola bahasa tanya juga lebih banyak digunakan dalam artikel-artikel di kategori ini, misalnya ketidakpastian dan keraguan tentang pandemi coronavirus. Selain itu, beberapa artikel yang diterbitkan juga mengandung keraguan dan kekhawatiran seperti mutasi genetik virus, klaim palsu dari ahli palsu, dan kebuntuan pengembangan vaksin di Indonesia.

Pola kalimat yang juga ditemukan dalam artikel artikel tirto.id adalah kalimat imperatif, yang banyak terdapat pada artikel dalam kategori kemanusiaan atau humaniora. Dalam kategori ini, konstruksi artikel dengan pola bahasa imperatif yang menurut Fairclough (2003) merupakan jenis bentuk bahasa yang cenderung dan lebih menuntut. Artinya, tipe kalimat ini mengharapkan imbalan dari pihak lain, dalam hal ini pembaca. Konteks situasional pada artikel dalam kategori ini juga lebih banyak membicarakan tentang kekacauan yang terjadi akibat pandemi, terutama untuk memberikan kesan bahwa pandemi coronavirus telah menciptakan kekacauan besar di masyarakat sehingga perlu bantuan untuk mengarahkan kembali umat manusia untuk mencapai lebih banyak strategi keamanan, ketahanan, dan adaptasi (de Amorim \& Guera, 2020).

Temuan inilah yang menggambarkan bagaimana kepanikan moral sebagai sebuah erupsi akar rumput bergejala. Pemberitaan dikonstruksikan sedemikian rupa, mengambil sudut pandang tertentu, dengan pilihan kata dan tata bahasa yang mengarah pada erupsi kepanikan moral. Publik yang telah mengalami health-scares semakin dibebankan dengan pemberitaan media tentang penanganan pemerintah yang buruk.

Pemberitaan yang dilakukan tirto.id mengindikasikan bahwa pemerintah juga berada dalam mode panik dalam menghadapi pandemi. Beragam kata deklaratif dan emotif menyiratkan keraguan dan ketidakpercayaan terhadap langkah pemerintah dalam menangani pandemi. Pemberitaan tirto.id tentang pemerintah di masa pandemi selalu memiliki bingkai yang sama, yaitu menunjukkan bahwa pemerintah tidak kompeten dalam menangani pandemi. Merujuk pada temuan yang ada, pada kategori politik dalam pemberitaan pandemi coronavirus di Indonesia selalu menggambarkan ketidakmampuan pemerintah dalam menangani masalah tersebut. Akibatnya, dapat dikatakan bahwa tirto.id memanfaatkan kekuatan framing media untuk mencontohkan informasi yang memicu kepanikan moral, dalam artian bahwa media massa modern memberikan percikan paling efektif untuk penciptaan kepanikan moral. Dengan membingkai pemerintah dalam karakteristik tertentu: tidak sesuai, panik, tidak konsisten; Tirto sengaja mendefinisikan peran pemerintah dalam masyarakat diskursif dari wacana kepanikan moral tentang pandemi coronavirus di Indonesia.

\subsection{Kepanikan Moral sebagai Manifestasi Kuasa Media}

Temuan yang ketiga dalam penelitian ini berkaitan dengan relasi kuasa (power relations) yang menjadi salah satu fokus penting dalam Analisis Wacana Kritis. Dalam menganalisis bagian ini, peneliti menemukan bahwa ada dua hal penting yang berkaitan dengan manifestasi kuasa media dalam pemberitaan tentang pandemi coronavirus di Indonesia.

Pertama, sebagai outlet media, tirto.id memiliki kuasa dalam struktur sosial yang memungkinkan mereka membentuk dan mengedarkan informasi kepada publik. Artinya bahwa pada tataran situasional, Tirto memiliki kekuatan untuk mengartikulasikan pandemi coronavirus ke dalam wacana khusus yang disajikan dalam liputannya. Tirto.id melabeli dirinya sebagai media yang berdiri di atas dan untuk semua kelompok, serta non-partisan, tidak bekerja untuk kepentingan politik apa pun. Dengan mengkonstruksi identitas institusionalnya, Tirto memberikan gambaran bahwa kekuasaan harus dipahami bukan sebagai properti, tetapi sebagai strategi yang terdiri dari manuver, teknik, dan fungsi (Foucault, 1990). Hal ini berarti bahwa publikasi yang dilakukan merupakan manifestasi dari kuasa media yang umumnya digunakan untuk mengontrol serta memengaruhi individu dan masyarakat luas lewat kekuatan ideologi dan informasi.

Tirto.id memiliki kewenangan untuk membentuk wacana pandemi coronavirus ke dalam liputannya, 
menyusun artikelnya menjadi tema, headline, fokus, dan highlight tertentu untuk menyajikan apa yang menurut mereka penting untuk diketahui publik. Hal tersebut bisa dilihat dari beberapa artikel yang menganalisis, menilai, dan membenarkan masalah-masalah tertentu yang terjadi akibat pandemi. Pada artikel pertama, "Benarkah Flu Musiman Lebih Mematikan daripada COVID-19?" tirto.id menyajikan informasi analitis tentang penyakit tersebut. Ketika masyarakat mulai panik dengan situasi ini, Tirto menerbitkan artikel berjudul "Alasan Mengapa Anda Harus Tenang Menghadapi COVID-19”.

Demikian pula dengan kasus yang terus meningkat dan menimbulkan masalah di publik, Tirto menyoroti masalah ini dengan menerbitkan artikel berjudul "Menimbun Masker, Menggali Kuburan Sendiri." Hal ini menunjukkan bahwa di tingkat masyarakat, Tirto memanifestasikan kekuatan institusionalnya untuk membentuk hubungan kekuasaan institusional dan sosial (Fairclough, 2001). Terlebih lagi, dengan mengkonstruksi liputannya dalam agenda tertentu, memilih sudut pandang dan topik tertentu, tirto.id sedang mengarahkan orang ke dalam perspektif tertentu tentang pandemi.

Kedua, manifestasi kuasa tirto.id sebagai media digunakan untuk menantang otoritas yang terlibat dalam isu ini, yakni pemerintah. Sebagai outlet media yang menekankan liputannya dalam jurnalisme presisi, tirto.id menjunjung tinggi laporan ilmiah, fakta, dan analisis mendalam sebagai bagian dari kekuatan yang mendikte wacana kepanikan moral dalam liputan pandemi coronavirus. Dengan demikian, tirto.id memiliki otoritas yang lebih besar dalam memicu manifestasi lain dari kepanikan moral, khususnya pada gagasan tentang kepedulian publik, kegiatan politik dan legislatif (Goode \& Ben-Yehuda, 2009).

Secara garis besar, pemberitaan tirto.id tentang pandemi coronavirus di Indonesia fokus pada lima kategori utama yaitu Sosial, Ekonomi, Kesehatan, Kemanusiaan dan Politik. Bisa dikatakan bahwa tirto.id sebagai outlet media melestarikan kekuatannya untuk mengaktifkan perhatian publik dan politisi dengan menekankan keseriusan fenomena, menetapkan agenda dan memberikan nada serta emosi tertentu ke dalam agenda pemberitaan yang dilakukan. Misalnya, dalam artikel berjudul Teledor Penanganan Wabah Covid-19 di Indonesia, tirto.id mengkritik keras pendekatan pemerintah dalam menangani pandemi dengan beberapa pernyataan seperti "lemahnya pengawasan di bandara," "pemerintah tidak serius" "pemerintah perlu mengklarifikasi" dan lain-lain. Pada bagian ini, pilihan kata dan frasa menjadi alat yang utama untuk menunjukkan kuasa sebagai media.

Penggunaan unsur-unsur tekstual seperti ragam pilihan kata, frasa, dan jenis kalimat menekankan wacana ke dalam fokus dan kerangka kepentingan tertentu. Pemanfaatan kekuasaan melalui pemilihan bahasa akan menguntungkan media dalam membentuk dan menyebarluaskan wacana ke dalam liputan. Dengan kata lain, tirto.id menggunakan kekuatannya untuk menggambarkan penderitaan dan kepanikan masyarakat sebagai akibat dari ketidakmampuan pihak - pihak tertentu yang bertanggung jawab dalam menangani masalah tersebut. Di masa pandemi, masyarakat perlu mencari informasi yang koheren dan paling dapat dipercaya, dan tirto.id berpihak pada perjuangan sosial ini sebagai outlet media yang menyediakan berita dan artikel mengenai hal ini.

Hasil yang sama juga ditemukan dalam penelitian Aslam et.al (2020) yang menunjukkan bahwa konotasi judul berita memiliki skor emosi yang tinggi dengan polaritas negatif di masyarakat, yang berarti bahwa apa yang dikonstruksi media dalam peliputannya akan berpengaruh pada bagaimana wacana diposisikan dalam kaitannya dengan perjuangan di tingkat situasional, sosial, dan kemasyarakatan (Fairclough, 2001).

Hasil penelitian ini menunjukkan bahwa tindakan tersebut tidak dilakukan oleh pemerintah Indonesia dalam menghadapi situasi kritis pandemi coronavirus sejak hari pertama kasus tersebut ditemukan di Indonesia. Wacana mengenai pandemi coronavirus di Indonesia dikonstruksi oleh tirto.id untuk menunjukkan kekuatan institusionalnya atas perjuangan masyarakat akibat situasi pandemi, dan pada saat yang sama mengarahkan bahwa pemerintah ambil bagian sebagai pihak yang bisa disalahkan.

\section{KESIMPULAN}

Penelitian ini menunjukkan bahwa media memiliki kekuatan; Kekuatan untuk membangun narasi, kekuatan untuk memengaruhi; dan kekuatan untuk mendikte informasi. Dalam kaitannya dengan wacana kepanikan moral, pemberitaan tirto.id tentang pandemi coronavirus di Indonesia menggambarkan bagaimana media menjalankan fungsi serta kekuatannya untuk membentuk pemahaman publik tentang suatu keadaan. Tirto.id berhasil mengekstrapolasi wacana pandemi coronavirus di Indonesia dalam 
sebuah komunitas diskursif dimana isu tersebut sebagai fenomena yang memicu ketakutan di masyarakat, ditanggapi secara tidak tepat oleh pemerintah sehingga menimbulkan masalah sosial tertentu seperti kekacauan, kejatuhan ekonomi, masalah sosial, masalah kemanusiaan, dan akhirnya, kepanikan moral. Tirto.id juga menunjukkan kekuatannya sebagai media berita yang memiliki pengaruh korektif dan pengaruh persuasif untuk mendikte informasi dan menantang otoritas.

Selain itu, temuan bahwa kepanikan moral dari pandemi coronavirus di Indonesia adalah fenomena erupsi akar rumput, tirto.id berkontribusi dengan mengandalkan kekuatan konstruksi naratif, khususnya dalam menggunakan bahasa tekstual untuk memperbesar kepanikan. Kepanikan pandemi coronavirus telah merajalela di masyarakat, dan tirto.id memperbesar ketakutan tersebut menjadi kepanikan moral dengan memberikan liputan yang tepat dan terpercaya yang disampaikan secara sensasional. Hal ini berarti bahwa framing adalah elemen penting untuk memastikan bahwa artikel mengandung bentuk bahasa, kalimat, kata, dan sudut tertentu untuk membangun pengetahuan yang diandaikan yang akan menyusun perspektif publik tentang masalah tersebut. Proses pembingkaian dalam liputan Tirto juga termasuk penggunaan sensasionalisme untuk melebihlebihkan narasi. Keterkaitan antara framing dan sensasionalisme dalam pemberitaan media berdampak pada terciptanya narasi kepanikan moral pandemi coronavirus di Indonesia.

Adapun penelitian ini dilakukan dengan menggunakan analisis wacana kritis sebagai metode. Karena itu, hasil penelitian ini diambil dari perspektif kualitatif yang berarti bahwa pada pendekatan yang berbeda terhadap materi yang sama, terdapat kemungkinan hasil yang berbeda. Karena itu saran untuk penelitian selanjutnya adalah mengambil pendekatan yang berbeda pada skala yang berbeda seperti studi kuantitatif, memperluas ukuran sampel dan memperkaya variasi media untuk memperoleh hasil yang lebih komprehensif

\section{DAFTAR PUSTAKA}

Amorim, Wellyngton Silva de, and José Baltazar Salgueirinho Osório de Andrade Guerra. 2020. "Pandemics, Global Risks and Adaptation: Challenges for a Changing World." Research in Globalization 2 (100023): 100023. https://doi. org/10.1016/j.resglo.2020.100023.
Anwar, Ayesha, Meryem Malik, Vaneeza Raees, and Anjum Anwar. 2020. "Role of Mass Media and Public Health Communications in the COVID19 Pandemic." Cureus, September. https://doi. org/10.7759/cureus.10453.

Aslam, Faheem, Tahir Mumtaz Awan, Jabir Hussain Syed, Aisha Kashif, and Mahwish Parveen. 2020. "Sentiments and Emotions Evoked by News Headlines of Coronavirus Disease (COVID-19) Outbreak." Humanities and Social Sciences Communications 7(1). https://doi.org/ 10.1057/s41599-020-0523-3.

Béland, Daniel. 2011. "THE UNHEALTHY RISK SOCIETY: Health Scares and the Politics of Moral Panic." In Moral Panics and the Politic of Anxiety, edited by Sean Hier, 224-34. 2 Park Square, Milton Park, Abingdon, Oxon, OX14 4RN: Routledge.

Cohen, Stanley2011. Folk Devils and Moral Panics: The Creation of the Mods and Rockers. London: Routledge.

Dijk, Teun A. van. 1993. "Principles of Critical Discourse Analysis." Discourse \& Society 4 (2): 249-83. https://doi.org/10.1177/0957926593004 002006.

Eriyanto. 2009. Analisis Framing. Yogyakarta: Lkis Yogyakarta.

Fairclough, Norman. 1995. Discourse and Social Change. Cambridge; Malden: Polity Press.

. 2001. Language and Power. 2nd ed. London: Routledge.

. 2003. Analysing Discourse: Textual Analysis for Social Research. London: Routledge.

Frye, William B. 2005. "A Qualitative Analysis of Sensationalism in Media." Graduate Theses, Dissertations, and Problem Reports, West Virginia University. https://researchrepository. wvu.edu/etd/3218.

Foucault, Michel. 1990. The History of Sexuality. Vol. 1, an Introduction. Harmondsworth: Penguin.

Gabrial, Brian. 2013. "“Alarming Intelligence': Sensationalism in Newspapers after the Raids at Harpers Ferry, Virginia, and St. Albans, Vermont"." In "SENSATIONALISM Murder, Mayhem, Mudslinging, Scandals, and Disasters in 19th-Century Reporting," 74-93. New Brunswick, New Jersey: Transaction Publishers.

Ghanem, Salma I., Maxwell McCombs, and Gennadiy Chernov. 2009. "Agenda Setting and Framing." In 21st Century Communication: A Reference Handbook 21st Century Communication: A Reference Handbook, 516-24. Thousand Oaks, CA: SAGE Publications, Inc. https://doi.org/10.4135/9781412964005.n57. 
Gilman, Sander L. 2010. "Moral Panic and Pandemics." The Lancet 375 (9729): 1866-67. https://doi.org/10.1016/s0140-6736(10)60862-8.

Goode, Erich, and Nachman Ben-Yehuda. 2009. Moral Panics: The Social Construction of Deviance. Chichester, U.K.; Malden, Ma: Wiley-Blackwell.

Ingraham, Chris, and Joshua Reeves. 2016. "New Media, New Panics." Critical Studies in Media Communication 33 (5): 455-67. https://doi.org/ 10.1080/15295036.2016.1227863.

Klemm, Celine, Enny Das, and Tilo Hartmann. 2014. "Swine Flu and Hype: A Systematic Review of Media Dramatization of the H1N1 Influenza Pandemic.” Journal of Risk Research 19 (1): 120. https://doi.org/10.1080/13669877.2014.923029.

McCombs, Maxwell, and Salma I. Ghanem. 2001. "The Convergence of Agenda Setting and Framing." In Framing Public Life, Perspectives on Media and Our Understanding of the Social World, edited by Stephen d. Reese, Oscar H Gandy, Jr, and August E. Grant, 67-82. New Jersey: Lawrence Erlbaum Associates, Inc.

Monod, Sarah Wright. 2017. Making Sense of Moral Panics. Cham Springer International Publishing.

Purba, Ririn. (2020). Kepanikan Sosial Akibat Munculnya Covid-19. Jurnal Penelitian Kesejahteraan Sosial, 19(2), 124-136. https://ejournal.kemensos.go.id/

PLOS Medicine Editors. 2008. "False Hopes, Unwarranted Fears: The Trouble with Medical News Stories." PLoS Medicine 5 (5): e118. https://doi.org/10.1371/journal.pmed.0050118
Reynolds, Barbara, and Matthew W Seeger. 2005. "Crisis and Emergency Risk Communication as an Integrative Model." Journal of Health Communication 10 (1): 43-55. https://doi.org/ 10.1080/10810730590904571

Satawedin, Patama. (2020). Moral Panics and COVID-19: Are We Panic Ourselves or Do Media Make Us Panic? Bangkok University Academic Review, 19(2), 207-224.https://so01. tcithaijo.org/index.php/buacademicreview/articl e/view/242758

Sobur, Alx. 2006. Analisis Teks Media, Suatu pengantar. Bandung: Remaja Rosdakarya.

The Jakarta Post. 2020. "Indonesia Shifts from 'New Normal' to 'Adapting to New Habits."' The Jakarta Post. July 11, 2020. https://www.thejakartapost.com/news/2020/07/11/indonesiashifts-from-new-normal-to-adapting-to-newhabits.html.

Wanta, Wayne, Guy Golan, and Cheolhan Lee. 2004. "Agenda Setting and International News: Media Influence on Public Perceptions of Foreign Nations." Journalism \& Mass Communication Quarterly 81(2): 364-77. https://doi.org/10. 1177/107769900408100209.

Wodak, Ruth, and Michael Meyer. 2001. Methods of Critical Discourse Analysis. 1st ed. SAGE Publisher Ltd. https://doi.org/10.4135/97808570 28020.

"Zen RS: Kami Ingin Membangun Kultur Riset Di Media - Remotivi." 2017. Www.remotivi.or.id. May 8, 2017. https://www.remotivi.or.id/ wawancara/434/zen-rs-kami-ingin-membangunkultur-riset-di-media. 